\title{
A botanical mystery solved by phylogenetic analysis of botanical garden collections: the rediscovery of the presumed-extinct Dracaena umbraculifera
}

\author{
Christine E. Edwards, Burgund Bassüner, Chris Birkinshaw \\ Christian Camara, Adolphe Lehavana, Porter P. Lowry Ii, James S. Miller \\ ANDREW Wyatt and Peter Wyse Jackson
}

\begin{abstract}
Extinction is the complete loss of a species, but the accuracy of that status depends on the overall information about the species. Dracaena umbraculifera was described in 1797 from a cultivated plant attributed to Mauritius, but repeated surveys failed to relocate it and it was categorized as Extinct on the IUCN Red List. However, several individuals labelled as D. umbraculifera grow in botanical gardens, suggesting that the species' IUCN status may be inaccurate. The goal of this study was to understand (1) where $D$. umbraculifera originated, (2) which species are its close relatives, (3) whether it is extinct, and (4) the identity of the botanical garden accessions and whether they have conservation value. We sequenced a cpDNA region of Dracaena from Mauritius, botanical garden accessions labelled as D. umbraculifera, and individuals confirmed to be $D$. umbraculifera based on morphology, one of which is a living plant in a private garden. We included GenBank accessions of Dracaena from Madagascar and other locations and reconstructed the phylogeny using Bayesian and parsimony approaches. Phylogenies indicated that D. umbraculifera is more closely related to Dracaena reflexa from Madagascar than to Mauritian Dracaena. As anecdotal information indicated that the living D. umbraculifera originated from Madagascar, we conducted field expeditions there and located five wild populations; the species' IUCN status should therefore be Critically Endangered because $<50$ wild individuals remain. Although the identity of many botanical garden samples remains unresolved, this study highlights the importance of living collections for facilitating new
\end{abstract}

Christine E. Edwards (Corresponding author), Burgund Bassüner, Porter P. Lowry II*, James S. Miller, Andrew Wyatt and Peter Wyse Jackson Missouri Botanical Garden, P. O. Box 299, St. Louis, MO 63166, USA

E-mail christine.edwards@mobot.org

Chris Birkinshaw, Christian Camara and Adolphe Lehavana, Missouri Botanical Garden, Madagascar Research and Conservation Program, Antananarivo, Madagascar

*Also at: Institut de systématique, évolution, et biodiversité, Unité mixte de Recherche 7205 (Centre national de la Recherche scientifique/Muséum national d'Histoire naturelle/École pratique des Hautes études, Université Pierre et Marie Curie), Muséum national d'Histoire Naturelle, Sorbonne Universités, Paris, France

Received 29 June 2017. Revision requested 13 September 2017.

Accepted 4 October 2017. First published online 8 January 2018 discoveries and the importance of documenting and conserving the flora of Madagascar.

Keywords Botanical garden, Dracaena reflexa, Dracaena umbraculifera, extinction, living collections, Madagascar, Mauritius, phylogeny reconstruction

\section{Introduction}

Ttinction is the complete and total loss of all individuals $\mathrm{C}$ of a species. In practice, extinction can be defined as 'the permanent absence of current and future records of a species' (Ladle et al., 2011). Although this is a relatively straightforward concept, accurately determining and proving that a species is extinct is far from straightforward. Many species may be presumed to be extinct, but whether this is actually the case may depend on factors such as the amount and accuracy of historical data on a species' distribution; the size of its range and the density of its populations; how its range has changed over time; the ease with which it can be observed in the field; and the number of knowledgeable scientists searching for it, the effort they expend in searching for it, and their overall knowledge of the biota of a region (Ladle et al., 2011; Lee et al., 2017). The most convincing evidence for extinction involves species that were once widespread and well known but then experienced an observable decline in range and population size, and cannot now be relocated despite a relatively complete knowledge of the biota of the region and extensive, repeated surveys by qualified biologists. If there is robust evidence for the extinction of a species, IUCN Red List working groups may determine it to be Extinct or Extinct in the Wild. A considerable number of plant species are known to be Extinct in the Wild but still persist in cultivation, mainly in botanical gardens.

Dracaena umbraculifera (Asparagaceae sensu lato, Byng et al., 2016) is an example of a plant species that is currently categorized as Extinct on the IUCN Red List (Strahm, 1998). To our knowledge it has never been observed by botanists in the wild and as a consequence has remained a mystery for several centuries. Described in 1797 by Nicolaus Joseph von Jacquin based on a plant cultivated in the greenhouses of the botanical garden at Schönbrunn in Vienna (see Plate 1a for original illustration, Jacquin, 1797), this species has a 
(a)
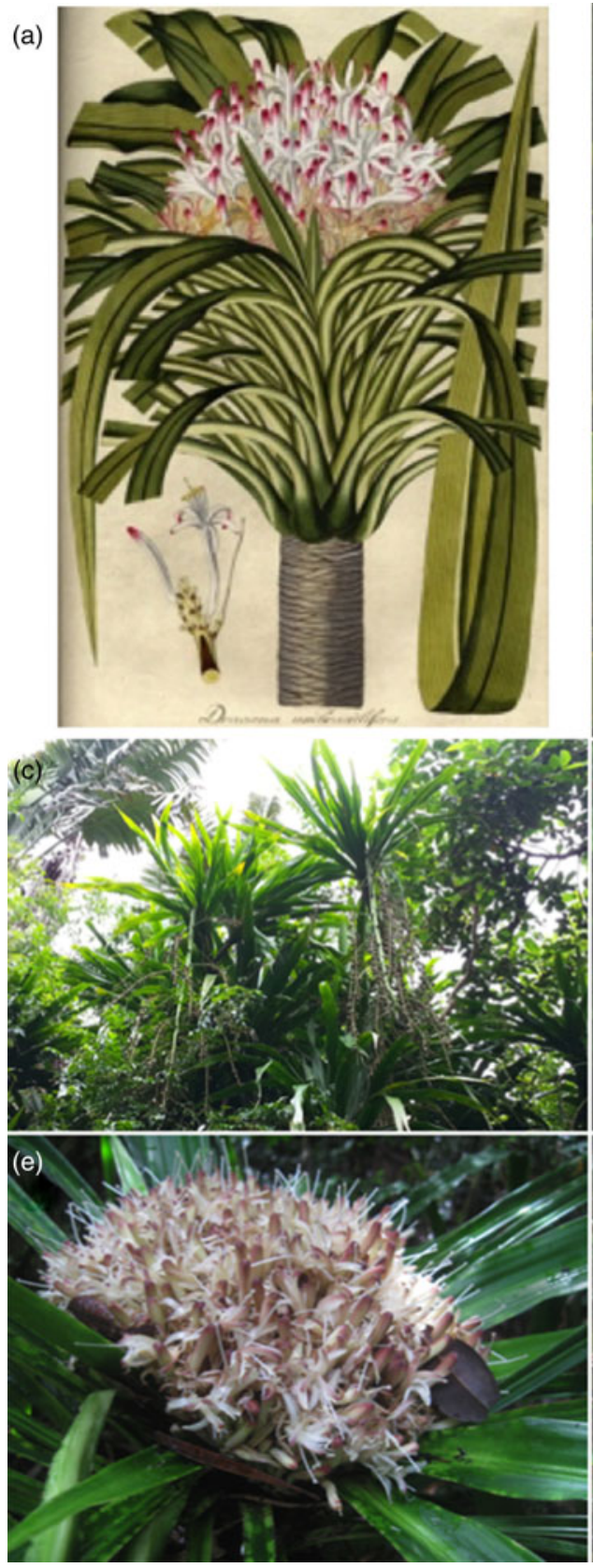
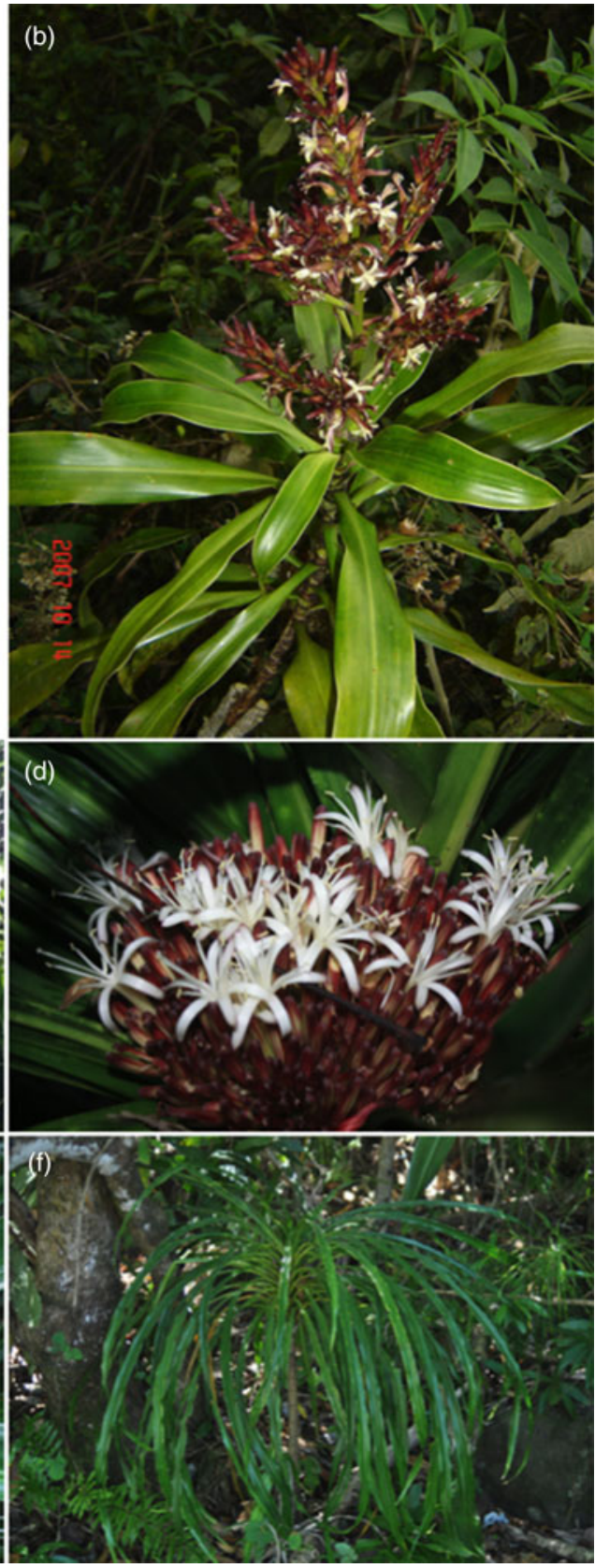

Plate 1 (a) The original illustration of Dracaena umbraculifera from Jacquin (1797), (b) a paniculate inflorescence of Dracaena reflexa in Madagascar (photograph by P. Antilahimena, collection number 5824), (c) a diffuse paniculate infructescence of Dracaena floribunda in Mauritius (photograph by C. Edwards), (d) a young inflorescence of $D$. umbraculifera in Ile Sainte-Marie (photograph by Rova Malala Rakotoarivelo), (e) an inflorescence of $D$. umbraculifera in Ile Sainte-Marie in full flower (photograph by A. Lehavana), and (f) a vegetative individual of D. umbraculifera (photograph by P. Lowry). distinctive morphology, with tightly clustered flowers in a nearly umbellate inflorescence in the centre of the leaves (Plate 1a), differing from the diffuse, paniculate inflorescences that characterize all other Dracaena (Plate $1 \mathrm{~b}$ ). Although Jacquin indicated that the cultivated plant on which he based his description came from the island of Mauritius (Jacquin, 1797), its origin is unclear. It may have been collected during a voyage made by Franz Boos and Georg Scholl, who sailed to South Africa and Mauritius during 1786-1787 and sent back 280 cases of plants, assembled by M. Céré of the Pamplemousses Botanical Garden in Mauritius. However, there is no surviving documentation of the plants contained in this shipment nor is it known whether they were all Mauritian natives. Dracaena umbraculifera is not present in the current collections of the Pamplemousses Botanical Garden (now the Sir Seewoosagur Ramgoolam Botanical Garden).

Dracaena umbraculifera was subsequently included in a list of plants of Mauritius (Bojer, 1837) and described as growing in the thick forests in the centre of the island and flowering very rarely. It was also listed as a Mauritian species in the Flora of Mauritius and the Seychelles (Baker, 1877). In the more recent Flore des Mascareignes (Marais \& Coode, 1978), doubt was expressed about whether D. umbraculifera was native to Mauritius, as the main evidence that it existed in Mauritius was Bojer's description. It was suggested that Bojer may have confused $D$. umbraculifera with Dracaena floribunda, which still occurs in central Mauritius, and 
that if D. umbraculifera was indeed Mauritian it must be extinct. Following unsuccessful efforts over the previous century to locate living plants in the wild, the species was categorized as Extinct in 1998 (Strahm, 1998).

Despite the fact that no natural population of D. umbraculifera has been documented in the wild in Mauritius, it may not be extinct, as living plants labelled as $D$. umbraculifera have long been grown in botanical gardens around the world. One such plant is growing at the Missouri Botanical Garden. This stimulated an interest in the true status of this presumably extinct species and led us to initiate a study to try to elucidate its origins. The individual at Missouri Botanical Garden was obtained in 1904 from an unknown source and, if correctly identified, the IUCN status of D. umbraculifera should be updated to Extinct in the Wild (IUCN, 2012). Further research in the database of cultivated plants maintained by Botanic Gardens Conservation International (BGCI, 2017) found 19 other gardens with living individuals identified as D. umbraculifera. Communications with staff at these gardens indicated that most of these plants have been in their collections for decades and their origins are unknown (other than in some cases in which they were obtained from other botanical gardens). As unequivocal morphological identification of these plants relies on the presence of an inflorescence, yet they rarely, if ever, flower in cultivation (the plant in Missouri Botanical Garden has not been observed in flower for decades), the identity of these specimens remains uncertain. It is important to determine their identity because they may be the only remaining individuals of a species that is otherwise extinct.

Our goal was to unravel the mystery of $D$. umbraculifera and, in particular, to understand where it originated, which species it is related to, whether it is indeed extinct in the wild, whether the living plants in botanical gardens are correctly identified and whether they are of conservation value. We gathered samples from living individuals labelled as $D$. umbraculifera from botanical gardens throughout the world, travelled to Mauritius to collect specimens of the extant species of Dracaena, and investigated phylogenetic relationships using this material, as well as GenBank accessions from species from other islands of the Western Indian Ocean. As our initial phylogenetic reconstruction based on DNA sequence data indicated that living plants identified as D. umbraculifera were more closely related to species in Madagascar than to those in Mauritius, we conducted fieldwork in Madagascar in an attempt to collect additional possible relatives and perhaps also locate the presumed-extinct $D$. umbraculifera.

\section{Methods}

\section{Sample collection and molecular methods}

We obtained leaf samples preserved in silica gel from living collections of 10 accessions identified as D. umbraculifera from 10 botanical gardens in seven countries (Table 1), as well as one cultivated accession of Dracaena reflexa from Missouri Botanical Garden. Individuals from botanical gardens identified as D. umbraculifera but that are not confirmed by a flowering specimen are hereafter indicated in quotes (i.e. 'D. umbraculifera'). Although other gardens reported having individuals of $D$. umbraculifera, several flowered recently and had diffuse-paniculate inflorescences, confirming that they were incorrectly identified, and were not included in the study. Leaf material of a correctly identified, pressed specimen of $D$. umbraculifera was obtained from the University of Vienna herbarium (WU o077694; Table 1). It was prepared in 1895 from a plant cultivated in the Hortus Botanicus Vindobonensis (now known as the Botanical Garden of the University of Vienna), and has the distinctive inflorescence of $D$. umbraculifera. Given that Jacquin, who described D. umbraculifera, was the first director of Hortus Botanicus Vindobonensis, we speculate that this specimen may have originated from the same plant on which Jacquin based his description.

We also conducted fieldwork in Mauritius in January 2014 to collect leaf tissue of all Dracaena species currently known to be native to the island (Table 2), including $D$. floribunda, D. concinna and $D$. reflexa (including two of the three varieties of D. reflexa in Mauritius, var. reflexa and var. angustifolia). The collected tissue was preserved in silica gel. During this trip, staff at Mauritius Herbarium informed us of an individual of D. umbraculifera growing in a private garden on the island. This plant had flowered recently and its identification was confirmed based on its distinctive, umbel-like inflorescence. The herbarium staff provided leaf tissue in silica gel, which was used as a reference for comparison with the samples obtained from botanical gardens. Although the wild origin of the plant was not indicated on the herbarium specimen, a web search found an online posting by the plant's owner indicating that it grows in N-East of Madagascar in an island called Ste Marie, Illes Aux Nattes' (Dave's Garden, 2007). This information as well as the results from preliminary phylogenetic analyses prompted us to visit Ile Sainte-Marie and its small outlier Ile aux Nattes, off the east coast of Madagascar, in October 2014, where three samples of two native Dracaena species were collected (Table 2).

DNA was extracted from the leaf tissue samples using a modified Cetyl trimethylammonium bromide (CTAB) approach (Doyle \& Doyle, 1987). As a recent molecular phylogenetic study that investigated relationships in Malagasy $D$. reflexa (Buerki et al., 2009) employed a plastid marker spanning the $\operatorname{trn} L$ gene and $\operatorname{trn} L-F$ spacer, we selected this marker for our study to make use of previously generated DNA sequence data. We conducted polymerase chain reactions (PCR) using the primers C and F (Taberlet et al., 1991) and previously published amplification protocols (Shaw et al., 2005). PCR products were cleaned with ExoSAP 
TABLE 1 Cultivated accessions of Dracaena umbraculifera and Dracaena reflexa used in phylogenetic analysis of Dracaena species.

\begin{tabular}{|c|c|c|c|c|c|c|}
\hline Label & Location & Accession number & $\begin{array}{l}\text { Type of } \\
\text { collection }\end{array}$ & $\begin{array}{l}\text { ID confirmed by } \\
\text { inflorescence? }\end{array}$ & Source & $\begin{array}{l}\text { GenBank } \\
\text { accession } \\
\text { number }\end{array}$ \\
\hline D. umbraculifera & $\begin{array}{l}\text { Vienna University } \\
\text { Herbarium, Vienna } \\
\text { Austria }\end{array}$ & WU0077694 (1895) & Herbarium & Yes & $\begin{array}{l}\text { Plant grown in } \\
\text { botanical gar- } \\
\text { den in Vienna } \\
(1895)\end{array}$ & MG020508 \\
\hline D. umbraculifera & $\begin{array}{l}\text { Personal garden of } \\
\text { I. Vencapah, Mont } \\
\text { Choisy, Mauritius }\end{array}$ & $\begin{array}{l}\text { Voucher deposited in } \\
\text { the Herbarium of the } \\
\text { Missouri Botanical } \\
\text { Garden: Vencapah } \\
26071\end{array}$ & Living & Yes & Unknown & MG020494 \\
\hline 'D. umbraculifera' & $\begin{array}{l}\text { Wairere Nursery, } \\
\text { Auckland, New } \\
\text { Zealand }\end{array}$ & & Living & No & Chiltern Seeds & MG020491 \\
\hline D. umbraculifera & $\begin{array}{l}\text { Dunedin Botanic } \\
\text { Garden, Dunedin, } \\
\text { New Zealand }\end{array}$ & & Living & No & Chiltern Seeds & MG020492 \\
\hline 'D. umbraculifera' & $\begin{array}{l}\text { Toronto Zoo, } \\
\text { Toronto, Canada }\end{array}$ & & Living & No & Unknown & MG020497 \\
\hline 'D. umbraculifera' & $\begin{array}{l}\text { Botanic Garden of } \\
\text { Smith College } \\
\text { Northampton, USA }\end{array}$ & 6360PA & Living & No & Unknown & MG020493 \\
\hline 'D. umbraculifera' & $\begin{array}{l}\text { Conservatoire } \\
\text { Botanique National } \\
\text { de Brest, France }\end{array}$ & $80-0330$ & Living & No & $\begin{array}{l}\text { Jardin } \\
\text { Botanique } \\
\text { Genève }\end{array}$ & MG020505 \\
\hline 'D. umbraculifera' & $\begin{array}{l}\text { Moscow Main } \\
\text { Botanic Garden, } \\
\text { Moscow, Russia }\end{array}$ & New \& old greenhouses & Living & No & $\begin{array}{l}\text { Grown from } \\
\text { seed (1968) }\end{array}$ & MG020496 \\
\hline 'D. umbraculifera' & $\begin{array}{l}\text { Komarov Botanical } \\
\text { Institute, } \\
\text { St. Petersburg, } \\
\text { Russia }\end{array}$ & & Living & No & Pre 1917 & MG020504 \\
\hline 'D. umbraculifera' & $\begin{array}{l}\text { Missouri Botanical } \\
\text { Garden, St. Louis, } \\
\text { USA }\end{array}$ & 1980-1301 & Living & No & $\begin{array}{l}\text { Unknown } \\
(1904)\end{array}$ & MG020495 \\
\hline 'D. umbraculifera' & $\begin{array}{l}\text { Jardin Botanique } \\
\text { Nancy, France }\end{array}$ & 1989.3.056, 1990.3.194 & Living & No & $\begin{array}{l}\text { Jardin } \\
\text { Botanique } \\
\text { Genève }\end{array}$ & MG020506 \\
\hline 'D. umbraculifera' & $\begin{array}{l}\text { Muséum national } \\
\text { d'Histoire naturelle, } \\
\text { Paris, France }\end{array}$ & $7460,58406,71595$ & Living & No & Unknown & MG020507 \\
\hline D. reflexa & $\begin{array}{l}\text { Missouri Botanical } \\
\text { Garden, St. Louis, } \\
\text { USA }\end{array}$ & $1989-4416$ & Living & & $\begin{array}{l}\text { Joseph Hill Co } \\
\text { Tropical } \\
\text { Foliage, Miami } \\
(1989)\end{array}$ & MG020498 \\
\hline
\end{tabular}

(USB Corporation, Cleveland, USA) and sequenced in both directions using BigDye Chemistry (Applied Biosystems (ABI), Foster City, USA) on an ABI 3730xl DNA Genetic Analyzer at the DNA analysis facility at Science Hill at Yale University, New Haven, USA. Forward and reverse sequences were assembled and edited in Geneious R8 (Kearse et al., 2012).

The new sequences generated in this study were aligned with the following 34 sequences from GenBank: 24 Dracaena from Madagascar (EUo32487-EU032510, Buerki et al., 2009);
'D. umbraculifera' from a cultivated specimen at the Waimea Arboretum and Botanical Garden, Haleiwa, USA (JQ904986, Lu \& Morden, 2014); three sequences of Dracaena from Asia and the Canary Islands, D. draco (KC439477), D. cambodiana (KC439478), and D. cochinchinensis (KC439475); multiple Asparagaceae s.l. outgroups, including Convallaria majalis (EU850171), Maianthemum gongshanensis (EU850177), Disporopsis aspersa (EU850172), Polygonatum cyrtonema (EU850170), and Cordyline cannifolia (KC428478); and one additional outgroup from another family of Asparagales, 
TABLE 2 Wild accessions of Dracaena species used in phylogenetic analysis. All voucher specimens are deposited in the Herbarium of the Missouri Botanical Garden.

\begin{tabular}{llll}
\hline Species & Location & Voucher & $\begin{array}{l}\text { GenBank accession } \\
\text { number }\end{array}$ \\
\hline D. floribunda & On the west banks of the Papaya River, Henrietta, Mauritius & Edwards 299 & MG020499 \\
D. reflexa var. reflexa & Brise Fer Conservation Management Area, Mauritius & Edwards 296 & MG020500 \\
D. reflexa var. reflexa & Mondrain Reserve, Mauritius & Edwards 300 & MG020501 \\
D. concinna & St. Martin cemetery, Baie du Cap, Mauritius & Edwards 301 & MG020503 \\
D. reflexa var. angustifolia & Black River Gorges National Park, Mauritius & Edwards 297 & MG020502 \\
D. umbraculifera & Kalalao Forest, Ile Sainte-Marie, Madagascar & Miller 10775 & MG020509 \\
D. umbraculifera & Kalalao Forest, Ile Sainte-Marie, Madagascar & Miller 10776 & MG020511 \\
D. xiphophylla & Kalalao Forest, Ile Sainte-Marie, Madagascar & Miller 10778 & MG020510 \\
\hline
\end{tabular}

Crinum oliganthum (AY139166; Amaryllidaceae), which was used to root the trees. Alignments were conducted using the default settings in Muscle (Edgar, 2004) and were adjusted manually in Geneious.

\section{Data analysis}

Phylogenetic analyses were carried out using parsimony and Bayesian approaches. Parsimony analysis was implemented in $P A U P^{*} 4.09152$ (Swofford, 2002) using heuristic searches, tree bisection-reconnection branch swapping and 1,000 random addition replicates, saving 100 trees per replicate. Bootstrap analyses (Felsenstein, 1985) with 1,00o replicates were employed to assess branch support, using a heuristic search with tree bisection-reconnection branch swapping, with one random addition per replicate and saving no more than one tree per replicate. Bayesian phylogenetic analysis was conducted using MrBayes 3.2 (Ronquist et al., 2012). The optimal model of evolution for the data was selected using the Akaike Information Criterion in jmodeltest (Darriba et al., 2012). We ran two analyses, using four chains each, three hot and one cold, the temperature set to the default of 0.2 , flat priors, and the GTR + G model of evolution as selected by jmodeltest. Analyses were run for 5 million generations, sampling a tree every 1,00o generations. To determine the burn-in value, we used Tracer v. 1.6 (Rambaut et al., 2014) to examine the stabilization of the run parameters and discarded trees saved before the stabilization of the scores. Posterior probabilities were calculated using the sumt command in MrBayes. Trees were visualized by constructing a majority-rule consensus of trees in the posterior distribution using $P A U P^{*}$.

\section{Results}

The final data set contained 55 sequences: 34 GenBank accessions and 21 sequences newly generated for this study, 13 of which were obtained from cultivated individuals (Table 1) and eight of which were from plants collected from the wild in Mauritius and Madagascar (Table 2). The aligned length of the $\operatorname{trn} L-F$ data matrix was 989 characters, of which 807 characters were constant, 93 were variable but parsimony-uninformative and 89 were parsimony-informative. Parsimony searches recovered 95,800 most-parsimonious trees with a length of 255 steps. Because the topologies of the trees obtained from Bayesian and parsimony phylogeny reconstruction were almost identical, we present only the Bayesian tree, with Bayesian posterior probabilities (PP) and parsimony bootstrap support (BS) indicated on branches (Fig. 1).

Using Crinum as the outgroup, the remaining samples were clustered into two well-supported clades (both with $\mathrm{PP}=1.0, \mathrm{BS}=100 \%$ ), one comprising two cultivated samples of ' $D$. umbraculifera' from New Zealand plus a sample of Cordyline, and the other containing all of the remaining taxa. Within the latter clade the accession of ' $D$. umbraculifera' from the Botanic Garden of Smith College, Northampton, USA, and the samples of M. gongshanensis, C. majalis and D. aspersa $+P$. cyrtonema were weakly supported, successive sisters to a well-supported clade $(\mathrm{PP}=1.0$, $\mathrm{BS}=74 \%$ ) containing all remaining Dracaena accessions (Fig. 1). This main Dracaena clade formed an unresolved polytomy comprising seven lineages: (1) a single GenBank accession of $D$. reflexa var. linearifolia, (2) a GenBank accession of 'D. umbraculifera' from the Waimea Arboretum and Botanical Garden, (3) a clade with $\mathrm{PP}=1.0$ and $\mathrm{BS}=81 \%$ containing three GenBank accessions of Dracaena from Asia and the Canary Islands, (4) a clade with $\mathrm{PP}=0.98$ and $\mathrm{BS}=61 \%$ that included one GenBank accession of Dracaena xiphophylla and two of D. reflexa var. angustifolia from northern Madagascar (i.e. clade C of Buerki et al., 2009), (5) a large clade with $\mathrm{PP}=0.65$ and $\mathrm{BS}=56 \%$ containing 13 samples of $D$. reflexa from the far northern Madagascar (i.e. clade A of Buerki et al., 2009), (6) a clade with $\mathrm{PP}=0.85$ and BS $=59 \%$ containing all six Dracaena accessions from Mauritius, and ( 7 ) a clade with $\mathrm{PP}=0.94$ and BS $<50 \%$ containing one single sample of D. xiphophylla from Ile Sainte-Marie placed as the sister group to a clade with $\mathrm{PP}=0.91$ and $\mathrm{BS}<50 \%$ containing an unresolved 


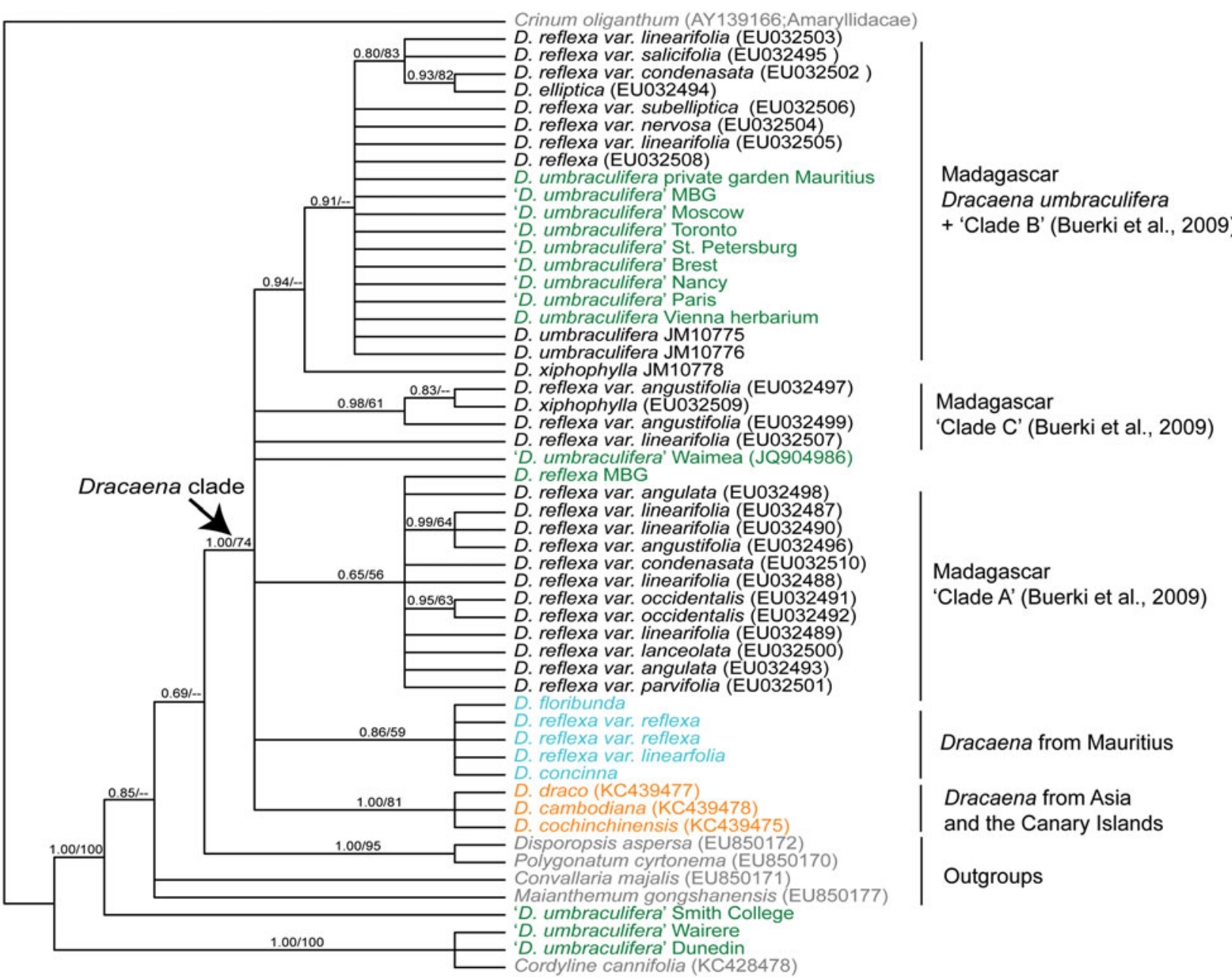

FIG. 1 Bayesian phylogeny of wild and cultivated Indian Ocean Dracaena spp., with Bayesian posterior probabilities/parsimony support values indicated on the branches. Plants from Madagascar are in black font; plants from Mauritius are in turquoise; cultivated plants are in green, with the name of the garden; Dracaena from elsewhere (outgroups) are in yellow; and outgroups are in grey. $D$. umbraculifera individuals whose identification has not been confirmed by reproductive material are indicated by quotation marks.

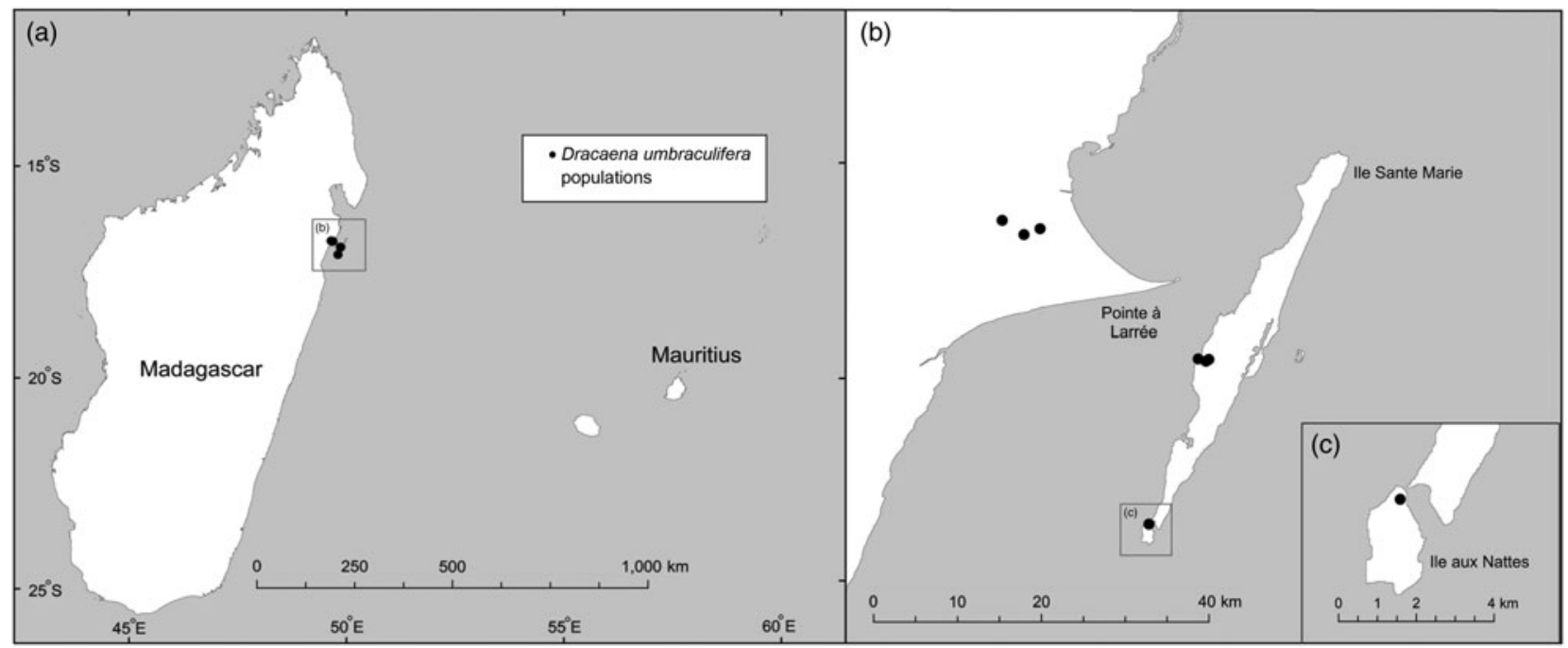

FIG. 2 Locations of D. umbraculifera populations in Madagascar from which samples were collected for phylogenetic analysis. 
polytomy of the two positively identified samples of D. umbraculifera (from Mauritius and Vienna, respectively), two samples from Ile Sainte-Marie, seven ' $D$. umbraculifera' accessions from botanical gardens (from Missouri, Moscow, Toronto, St. Petersburg, Paris, Brest and Nancy) and eight samples of $D$. reflexa from coastal north-eastern and northcentral Madagascar (i.e. clade B of Buerki et al., 2009).

\section{Discussion}

The origin and closest relatives of Dracaena umbraculifera

The phylogenetic analyses presented here indicate that all species of Dracaena currently occurring in Mauritius form a well-supported clade, whereas the two samples positively identified as $D$. umbraculifera (i.e. the herbarium sample from Vienna and the living plant in the private garden, with an umbel-like inflorescence) are more closely related to a clade comprising multiple samples of $D$. reflexa from Madagascar (i.e. clade B of Buerki et al., 2009), suggesting that D. umbraculifera may not be a Mauritian species. Previous phylogenetic analysis of $D$. reflexa in Madagascar recovered three clades that were generally distributed according to geography, two that included samples from far northern Madagascar (i.e. clades A and C of Buerki et al., 2009) and one (i.e. clade B of Buerki et al., 2009) containing accessions from coastal north-eastern and north-central Madagascar, along with a few accessions from the southern portion of the country. Our analysis also showed that $D$. umbraculifera formed a clade with individuals of $D$. reflexa belonging to clade B (Buerki et al., 2009), which provided some indication of its likely geographical origin (i.e. coastal north-eastern and north-central Madagascar). The interpretation that $D$. umbraculifera may be of Malagasy origin was consistent with the information provided by the owner of the positively identified plant in a private garden in Mauritius, which prior to this study was the only known living individual unambiguously attributable to the species. Fieldwork in Madagascar in 2014 and 2015 led to the discovery of several wild populations in Ile Sainte-Marie and Ile aux Nattes, and further searches at Pointe à Larrée on the mainland, directly across from Ile Sainte-Marie, found additional wild populations (Fig. 2).

Although D. umbraculifera has always been considered to be a Mauritian species, the geographical distribution of the wild populations indicate that it is native to Madagascar. Phylogenies also suggest that it is more closely related to Malagasy species than Mauritian species, indicating that $D$. umbraculifera most likely originated in Madagascar. Because we included the herbarium sample from Vienna, which is probably derived from the type specimen, we can be certain about the identification of $D$. umbraculifera and the overall phylogenetic placement of the species. The most likely reason that this species has remained a mystery to botanists for centuries and has long been considered to be extinct is that it was attributed incorrectly to Mauritius. Records accompanying 18th century material from the western Indian Ocean were often scanty at best, and it is likely that the original plant on which Jacquin based his description was obtained in a shipment of plants from the Pamplemousses Garden in Mauritius, leading to its misattribution to that island. That the species was never detected in Madagascar is not particularly surprising given the country's extensive botanical diversity and endemism, the high vegetative similarity and taxonomic uncertainty of Malagasy Dracaena, and the lack of comprehensive, expert knowledge of the Dracaena of the region. Although it is possible that $D$. umbraculifera once occurred in the wild in Mauritius and went extinct, the phylogenetic analysis indicates that $D$. umbraculifera probably originated in Madagascar, which would require a relatively recent colonization event by $D$. umbraculifera from Madagascar to Mauritius, followed by its extinction in Mauritius, which is a less parsimonious explanation.

\section{Current status of Dracaena umbraculifera}

Surveys conducted during two field trips in 2014 and 2015 located a total of five wild populations of $D$. umbraculifera (Fig. 2), all of which occur in low-elevation evergreen forest on laterite and sandy soils. Three closely spaced populations occur in partially degraded forest at Pointe à Larrée on mainland Madagascar (Fig. 2), one inside the recently established (in April 2015) protected area being managed jointly by the local community and Missouri Botanical Garden, and two that are unprotected. A fourth population occurs in Ile aux Nattes (Fig. 2), on private land in highly disturbed secondary vegetation. The fifth population is located in largely intact, closed-canopy evergreen forest at Kalalao on Ile Sainte-Marie (Fig. 2). A few additional, apparently planted individuals occur on Sainte-Marie in private gardens.

Although our findings demonstrate that $D$. umbraculifera is clearly not extinct, it is nevertheless rare and faces many threats. Despite being known from five populations on Ile Sainte-Marie and mainland Madagascar, we estimate that no more than 50 mature individuals of $D$. umbraculifera remain in the wild, all of which face threats from habitat degradation, land clearing for agriculture and development, fires, and cyclones. The total number of individuals is below the threshold for Critically Endangered status under IUCN Red List Criterion D (IUCN, 2012). The species has an Extent of Occurrence of $949 \mathrm{~km}^{2}$ and an Area of Occupancy of $24 \mathrm{~km}^{2}$, and is facing continued decline in the quality of its habitat and the number of mature 
individuals. As with many threatened species in Madagascar, efforts to conserve D. umbraculifera should focus on protecting and restoring the forest fragments that harbour the wild populations. Establishing back-up collections of the species in ex situ facilities should also be carried out to contribute to its long-term conservation.

\section{Taxonomic implications}

Our results indicate that $D$. reflexa, as currently circumscribed, is not monophyletic. Material from Mauritius assigned to this species forms a clade with the two other Mauritian natives $D$. floribunda and D. concinna, indicating that ' $D$. reflexa' in Mauritius is evolutionarily distinct from populations in Madagascar and therefore should be referred to under a different name. Our results also show that $D$. reflexa clade B of Buerki et al. (2009) is more closely related to D. umbraculifera, which occurs in the same geographical area, than to other populations from northern Madagascar also assigned to $D$. reflexa, indicating that $D$. reflexa in Madagascar is also not monophyletic. As currently circumscribed, $D$. reflexa occurs throughout the islands of the Western Indian Ocean region, including Madagascar, Mauritius, Rodrigues, Réunion and the Seychelles archipelago, and also in Mozambique in continental Africa (Wright, 1901; eMonocot, 2010). Given the geographical structuring of lineages observed in Mauritius and Madagascar, it is possible that populations currently assigned to ' $D$. reflexa' occurring in these geographically isolated regions represent distinct lineages and thus belong to more than one species. It is also possible that some of these lineages occurring in islands in the western Indian Ocean could be close relatives of D. umbraculifera. However, this study included only a small portion of the diversity present in Madagascar and Mauritius, did not include Dracaena from other locations in the Indian Ocean region, and lacked the phylogenetic resolution needed to elucidate phylogenetic relationships fully. A future study employing more informative molecular markers (i.e. those generated using next-generation DNA sequencing approaches, such as RAD-seq or whole chloroplast genomes) and more comprehensive taxon sampling of Dracaena in Madagascar, Eastern Africa and the islands of the Western Indian Ocean is needed to clarify species boundaries, evolutionary relationships and patterns of diversity, and identify species in need of conservation.

\section{Status of the botanical garden collections}

The phylogenetic analyses presented here have helped to resolve the identification of some of the sampled individuals identified as ' $D$. umbraculifera' in botanical gardens. Several are clearly misidentified, including those growing in the Botanical Garden at Smith College and the accessions from New Zealand, which were placed among other Asparagaceae outgroups outside Dracaena in the phylogenetic tree. Our phylogenetic analyses did not, however, provide adequate resolution to confirm the identification of the remaining botanical garden accessions; their conservation importance thus remains unresolved. Despite the fact that several botanical garden samples (from Missouri Botanical Garden, France, Russia and Toronto) were placed in the clade that contained individuals confirmed to be D. umbraculifera, this group also included accessions that belong to the D. reflexa clade B (Buerki et al., 2009), and we were unable to determine to which group the botanical garden samples belong. In the absence of flowering material, future research using additional sampling and more informative molecular markers (i.e. collected using next-generation DNA sequencing approaches) will be necessary to confirm the identity of these botanical garden samples as well as to assess their genetic diversity and their value for conservation or reintroduction.

This study highlights the value and importance of the living collections maintained in botanical gardens, even those that are over a century old and lack information about their origin. Genetic analysis of living collections can play an important role in gaining a better understanding of poorly known species and making new discoveries of interest for biodiversity and conservation. In the past, plants of unknown origin have often been regarded as being of little or no value for conservation purposes. However, this research would never have been undertaken and D. umbraculifera would probably not have been rediscovered in Madagascar if we had not used genetic analysis to elucidate the true identity of the living collections of ' $D$. umbraculifera.' Genetic analysis of living collections will unquestionably bring new value to undocumented living collections in botanical gardens and facilitate their use for conservation purposes, such as for reintroductions and augmentations of depleted gene pools of wild populations of some Critically Endangered species.

Our findings also highlight the need for additional work in Madagascar and other islands of the western Indian Ocean. Madagascar contains an estimated 14,000 vascular plant species, of which nearly $90 \%$ are thought to be endemic (Callmander et al., 2011; Madagascar Catalogue, 2017), and many are threatened as a result of extensive and ongoing deforestation. Although Madagascar has been the focus of plant taxonomic work for over 2 centuries, comprehensive, expert knowledge of many taxa in the region is lacking, and many endemic species are poorly known. As previously stated, D. umbraculifera was overlooked by botanists in Madagascar because of the extensive botanical diversity and endemism there, the high vegetative similarity and taxonomic uncertainty of Malagasy Dracaena, and the lack of comprehensive, expert knowledge of the Dracaena of the region. An accurate understanding of the status of a 
species is necessary to devise effective conservation strategies, and therefore we emphasize the urgent need to document and conserve the biodiversity of this region, particularly in poorly understood groups such as Dracaena.

\section{Acknowledgements}

We are grateful to Imran Vencapah (Mauritius) for sharing his discovery of Dracaena umbraculifera in Madagascar; and Michael Kiehn and Walter Till (Vienna University Herbarium), Rob Nicholson (Smith College), Tom Myers (Dunedin Botanic Garden), Jody Lusk (Wairere Nursery), Elizabeth Miller (National Forestry Herbarium, New Zealand), Dmitry Geltman (Botanical Institute of St. Petersburg), Pete Phillipson (Missouri Botanical Garden), Aleksander Demidov (Moscow Main Botanic Garden), Claudia Baider (Mauritius Herbarium), Pei-Luen $\mathrm{Lu}$ (University of Hawaii at Manoa), Chad Husby (Fairchild Tropical Garden), Günter Gerlach (Munich Botanical Garden), Martin Callmander (Conservatoire et Jardin Botaniques de la Ville de Genève), Sven Buerki (Natural History Museum, London), Fanch Le Hir (Conservatoire Botanique National de Brest), and staff at the Toronto Zoo and the botanical gardens in Nancy for providing samples. We also thank Jean-Claude Sevathian, Vikash Tatayah, Debby de Chazal, Carl Jones and Gabriel d'Argent (Mauritian Wildlife Foundation) for helping obtain permits and locating specimens in Mauritius; Mario Allet, Arveen Gungadurdoss and Dharma Beetun of the National Parks and Conservation Service of Mauritius for assisting with field work in Mauritius; Rova Malala Rakotoarivelo for use of her photograph of D. umbraculifera; Theo Damen (Naturalis Biodiversity Centre, Netherlands) for discussions about D. umbraculifera; and Peter Hoch (Missouri Botanical Garden) for overall assistance obtaining samples.

\section{Author contributions}

CEE, JSM, AW and PWJ conceived the study. CEE, JSM, AW, CB and PWJ conducted fieldwork in Mauritius. AW and PWJ coordinated collection of material in botanical gardens. JSM, AL, PPL, CB and CC coordinated and conducted fieldwork in Madagascar. CEE and BB conducted the molecular work. CEE analysed the data. CEE and JSM wrote the article, and all authors edited and approved the final version.

\section{References}

B AKer, J.G. (1877) Flora of Mauritius and the Seychelles. Reeve \& Co., London, UK.
BGCi (Botanic Gardens Conservation International) (2017) PlantSearch. Https://www.bgci.org/plant_search.php [accessed 13 September 2013].

Bojer, W. (1837) Hortus Mauritianus. Aimé Mamarot et Compagnie, Mauritius.

Buerki, S., Callmander, M.W., Schüpfer, F., Ravokatra, M., Küpfer, P. \& Alvarez, N. (2009) Malagasy Dracaena Vand. ex L. (Ruscaceae): an investigation of discrepancies between morphological features and spatial genetic structure at a small evolutionary scale. Plant Systematics and Evolution, 280, 15-28.

Byng, J.W., Chase, M.W., Christenhusz, M.J.M., Fay, M.F., Judd, W.S., Mabberley, D.J. et al. (2016) An update of the Angiosperm Phylogeny Group classification for the orders and families of flowering plants: APG IV. Botanical Journal of the Linnean Society, $181,1-20$.

Callmander, M.W., Phillipson, P.B., Schatz, G.E., Andriambololonera, S., Rabarimanarivo, M., Rakotonirina, N. et al. (2011) The endemic and non-endemic vascular flora of Madagascar updated. Plant Ecology and Evolution, 144, 121-125.

Darriba, D., Taboada, G.L., Doallo, R. \& Posada, D. (2012) jModelTest 2: more models, new heuristics and parallel computing. Nature Methods, 9, 772.

Dave's Garden (2007) Dracaena or Yucca? Http://davesgarden.com/ community/forums/t/697465/\#b [accessed 12 October 2017].

Doyle, J.J. \& Doyle, J.L. (1987) A rapid isolation procedure for small quantities of fresh leaf tissue. Phytochemical Bulletin, 19, 11-15.

EdGAR, R.C. (2004) MUSCLE: a multiple sequence alignment method with reduced time and space complexity. BMC Bioinformatics, 5, 119.

eMоnосот (2010) Dracaena reflexa Lam. Http://e-monocot.org/ taxon/urn:kew.org:wcs:taxon:304786 [accessed 21 September 2017].

Felsenstein, J. (1985) Confidence limits on phylogenies: an approach using the bootstrap. Evolution, 39, 783-791.

IUCN (2012) IUCN Red List Categories and Criteria: Version 3.1. 2nd edition. IUCN, Gland, Switzerland, and Cambridge, UK.

Jacquin, N.J. (1797) Plantarum Rariorum Horti Caesarei Schoenbrunnensis.

Kearse, M., Moir, R., Wilson, A., Stones-Havas, S., Cheung, M., STURrock, S. et al. (2012) Geneious Basic: an integrated and extendable desktop software platform for the organization and analysis of sequence data. Bioinformatics, 28, 1647-1649.

Ladle, R.J., Jepson, P., Malhado, A.C.M., Jennings, S. \& Barua, M. (2011) The causes and biogeographical significance of species rediscovery. Frontiers of Biogeography, 3, 111-118.

Lee, T.E., Fisher, D.O., Blomberg, S.P. \& Wintle, B.A. (2017) Extinct or still out there? Disentangling influences on extinction and rediscovery helps to clarify the fate of species on the edge. Global Change Biology, 23, 621-634.

Lu, P.L. \& Morden, C.W. (2014) Phylogenetic relationships among Dracaenoid genera (Asparagaceae: Nolinoideae) inferred from chloroplast DNA loci. Systematic Botany, 39, 90-104.

Madagascar Catalogue (2017) A Catalogue of the Vascular Plants of Madagascar. Missouri Botanical Garden, St. Louis, USA.

Marais, W. \& Coode, M.J.E. (1978) 183. Lilacees. In Flore des Mascareignes (eds J. Bosser, T. Cadet, H.R. Julien \& W. Marais), p. 20. Mauritius Sugar Industry Research Institute, Mauritius, and Royal Botanic Gardens (Kew), London, UK.

Rambaut, A., Suchard, M.A., Xie, D. \& Drummond, A.J. (2014). Tracer v. 1.6. Http://tree.bio.ed.ac.uk/software/tracer/ [accessed 17 October 2017].

Ronquist, F., Teslenko, M., van der Mark, P., Ayres, D.L., Darling, A., HöHnA, S. et al. (2012) MrBayes 3.2: efficient Bayesian 
phylogenetic inference and model choice across a large model space. Systematic Biology, 61, 539-542.

Shaw, J., Lickey, E.B., Beck, J.T., Farmer, S.B., Liu, W.S., Miller, J. et al. (2005) The tortoise and the hare II: relative utility of 21 noncoding chloroplast DNA sequences for phylogenetic analysis. American Journal of Botany, 92, 142-166.

Strahm, W. (1998) Dracaena umbraculifera. In The IUCN Red List of Threatened Species 1998: e.T35017A9903551. Http://dx.doi.org/10. 2305/IUCN.UK.1998.RLTS.T35017A9903551.en [accessed 11 October 2017].

Swofford, D.L. (2002) PAUP*. Phylogenetic Analysis Using Parsimony ( ${ }^{*}$ and Other Methods). 4.10 beta 10. Sinauer Associates, Sunderland, USA.

Taberlet, P., Gielly, L., Pautou, G. \& Bouvet, J. (1991) Universal primers for amplification of three non-coding regions of chloroplast DNA. Plant Molecular Biology, 17, 1105-1109.
Wright, H. (1901) Observations on Dracaena reflexa Lam. Annals of the Royal Botanical Garden, Peradenia, 1, 165-172.

\section{Biographical sketches}

Christine Edwards and Burgund Bassüner are interested in using conservation genetics to ensure the effectiveness of conservation efforts for rare plant species. CHRIS Birkinshaw, CHRISTIAN Camara, Adolphe Lehavana, Porter P. Lowry II and James Miller are interested in taxonomy and conservation of the flora of Madagascar and Africa. Andrew Wyatt and Peter WYSE JACKSON are broadly interested in conservation activities in botanical gardens, and using botanical garden living collections for ex situ conservation of rare plant species. 